\title{
Konsep Reduce, Reuse, Recycle dan Replace dalam Pengelolaan Sampah Rumah Tangga di Desa Polanharjo Kabupaten Klaten
}

\author{
Nurul Istiqomah ${ }^{1, *} \mid$ Izza Mafruhah $^{1}$ | Evi Gravitiani ${ }^{1}$ | Supriyadi ${ }^{2}$ \\ ${ }^{1}$ Fakultas Ekonomi dan Bisnis, Universitas Sebelas Maret \\ ${ }^{2}$ Fakultas Pertanian, Universitas Sebelas Maret
}

\begin{abstract}
Abstrak
Indonesia merupakan negara penyumbang sampah plastik terbesar kedua di dunia setelah China. Berdasarkan data dari Kementerian Lingkungan Hidup dan Kehutanan (KLHK), diperkirakan jumlah sampah Indonesia pada tahun 2019 adalah sebesar 68 juta ton, dan sampah plastiknya mencapai 9,52 juta ton atau mencapai $14 \%$ dari total sampah yang ada. Pengelolaan sampah anorganik yang berupa botol, kertas, plastic, kaleng dan sampah bekas alat elektronik sifatnya lebih sukar terurai oleh organisme sehingga bertahan lama menjadi sampah. Terdapat berbagai cara untuk mengatasi masalah tersebut, yaitu 3R (Reduce, Reuse, dan Recycle). Sampah yang bisa diangkut ke TPA di Klaten setiap harinya hanya berkisar $70 \%$ dari sampah yang ada, dan yang bisa diolah menjadi kompos dan daur ulang sampah anorganik hanya berkisar $2 \%$, sedangkan sisanya ditimbun sebesar $10 \%$, dibakar sebesar $10 \%$ dan besarnya sampah yang tidak terangkut adalah $8 \%$. Polanharjo merupakan salah satu daerah di Kabupaten Klaten yang sudah mengkoordinasi pemanfaatan sampah anorganik secara komersil, salah satu pelaku pemanfaatan sampah didaerah tersebut adalah Bank Sampah Rukun Santoso. Bank Sampah Rukun Santoso merupakan salah satu bank sampah yang bisa mengelola dengan baik sampah yang dikumpulkannya, tetapi masih menghadapi beberapa kendala. Kendala-kendala tersebut adalah belum adanya variasi terhadap produk olahan sampah yang dihasilkan, karena baru bisa mengolah sampah berbahan dasar plastis pembungkus minuman instan saja. Sampah yang berupa kertas masih dijual secara kiloan, padahal mempunyai potensi untuk diolah dan mendapatkan nilai tambah yang lebih tinggi. Pemasaran yang dilakukan masih tradisional, dimana produk hasil olahan sampah hanya dipajang pada etalase di salah satu teras rumah pengurus dari bank sampah, sehingga diperlukan pelatihan untuk pemasaran yang lebih modern serta perlunya brand awareness pada produk olahan sampah tersebut. Tujuan dari pengabdian ini adalah melakukan pelatihan bagi anggota dan pengurus Bank Sampah di Desa Polanharjo untuk membuat produk baru sebagai usaha diversifikasi terhadap produk yang sudah ada untuk kemajuan usaha mereka dengan bahan baku kain perca, karena selama ini yang diolah hanya sampah plastis yang berupa bekas pembungkus minuman kemasan saja.
\end{abstract}

Keyword : Bank Sampah, Reduce, Reuse, Recycle, Sampah.

\section{Latar Belakang}

Keberadaan sampah tidak bisa dilepaskan dari kegiatan dari keberadaan manusia. Semakin banyak manusia, maka akan semakin banyak dan beragam sampah yang dihasilkan. Struktur perekonomian Indonesia yang bertumpu pada sektor industri, juga memberikan sumbangan bagi peningkatan volume sampah yang dihasilkan. Beberapa peraturan pemerintah telah dikeluarkan untuk pengelolaan sampah supaya tidak merugikan manusia. Beberapa peraturan tersebut antara lain adalah Undang-undang Nomor 18 Tahun 2008 mengenai Pengelolaan Sampah, Peraturan Pemerintah (PP) Nomor 81 Tahun 2012 tentang Sampah Rumah Tangga, serta beberapa peraturan mengenai sampah lainnya.

Kementerian Lingkungan Hidup dan Kehutanan (KLHL) mengeluarkan suatu program yang bernama Indonesia Bebas Sampah 2020, dan mulai dikampanyekan pada bulan Februari 2016. Program tersebut membutuhkan usaha dan komitmen yang keras dari seluruh rakyat Indonesia. Adapun penanganan sampah tersebut dapat dilakukan dengan program-program yang direncanakan, salah satunya dengan

\footnotetext{
${ }^{*}$ Penulis Korespondensi. Email: nurulistiqomahı800@yahoo.com
} 
Program Indonesia Peduli Sampah yaitu dengan 3R (Reduce, Reuse, Recycle). Budaya 3R dikembangkan dari diri sendiri dan mengubah cara pandang masyarakat bahwa sampah merupakan

Bank Sampah Rukun Santoso merupakan bank sampah yang terdapat di Polanharjo Kabupaten Klaten, yang menerapkan pengelolaan sampah berbasis masyarakat. Bank sampah ini cukup berhasil dalam memberdayakan masyarakat melalui pelibatan anggota bank sampah untuk mengelola dan memproduksi barang-barang hasil daur ulang sampah yang dikumpulkan. Produk unggulan dari Bank Sampah Rukun Santoso adalah pembuatan produk tas, dompet serta tas laptop yang berasal dari sampah plastis. Sampah yang berasal dari plastis merupakan salah satu jenis sampah yang sulit untuk diuraikan dalam waktu pendek. Jumlah sampah plastis di Indonesia tahun 2019 diperkirakan sebesar 9,52 juta ton atau hampir $14 \%$ dari total sampah yang ada. Oleh karena itu, pemanfaatan sampah plastis yang digunakan sebagai produk unggulan Bank Sampah Rukun Santoso merupakan nilai lebih yang bisa disumbangkan kepada lingkungan dan masyarakat. Berikut adalah produk-produk unggulan Bank Sampah Rukun Santoso.
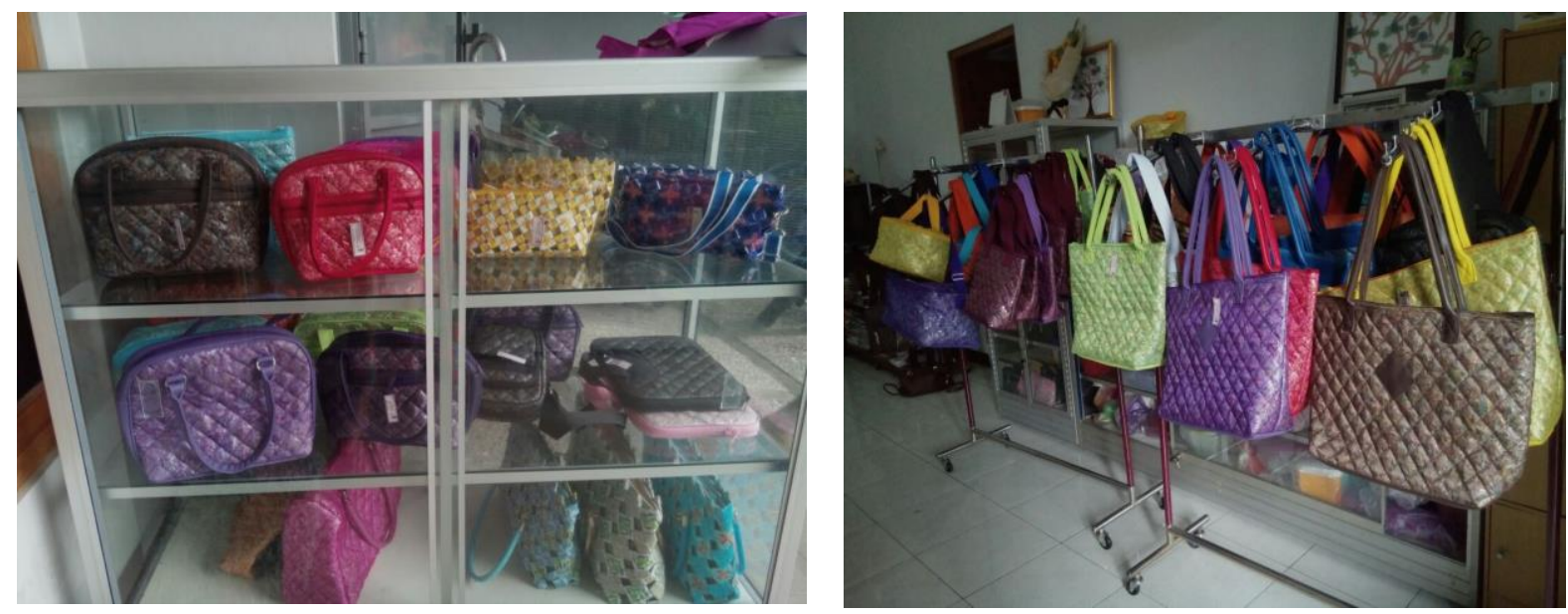

Gambar 1. Produk Olahan Sampah Plastik di Bank Sampah Rukun Santoso

Hasil produk olahan sampah yang berasal dari plastik tersebut sudah dapat diterima masyarakat dan mempunyai pangsa pasar di daerah Klaten dan sekitarnya. Dengan berbahan baku plastik bekas pembungkus minuman instan seperti kopi, permen, snack dan lain-lain maka dapat dihasilkan berbagai produk tas yang mempunyai harga yang sepadan dan jelas memberikan masukan pendapatan kepada anggota Bank Sampah Rukun Santoso. Hasil kreativitas dari pengurus dan anggota dari Bank Sampah ini dalam mengelola sampah plastis mendapat apresiasi yaitu menjadi percontohan bagi pengelolaan bank sampah di daerah lain.

Berdasarkan pengamatan, masih didapati beberapa kelemahan dan kekurangan yang ada pada Bank Sampah Rukun Santoso ini, diantaranya produk yang dihasilkan masih berbahan baku pada produk plastik saja dan hanya dimanfaatkan untuk produk tas, serta sampah-sampah jenis lain masih dijual dalam bentuk kiloan karena belum bisa untuk diolah menjadi produk lain. Sampah yang masih dijual dalam bentuk kiloan adalah gelas bekas minuman kemasan, kertas bekas serta sampah yang berupa kain perca. Selain itu, Bank Sampah Rukun Santoso masih mengalami keterbatasan dalam kapasitas produksi karena mesin jahit yang digunakan untuk membuat tas hanya ada satu mesin dan merupakan pinjaman dari anggota bank sampah tersebut sehingga ketika mendapat pesanan dalam jumlah yang banyak sering menolak.

Pengabdian tahun pertama yang dilakukan pada komunitas Bank Sampah Rukun Santoso adalah memberikan pelatihan mengenai diversifikasi produk yang bisa dihasilkan dari sampah plastic yang berasal dari gelas minuman instan serta dari kertas bekas. Dengan menghadirkan dua orang tenaga ahli untuk melatih pengolahan sampah tersebut. Gelas bekas minuman instan/ minuman mineral bisa diolah 
menjadi beberapa produk, diantaranya adalah untuk membuat tirai pada jendela atau penyekat antar ruangan, bros serta sebagai tempat untuk menyimpan pernak pernik. Selain itu, juga dilatih untuk mengolah bekas tas plastic yang bisa dimanfaatkan sebagai bros maupun sebagai bunga hiasan pada set tempat minuman kemasan gelas yang biasanya ditaruh di ruang tamu. Antusias masyarakat peserta pelatihan sangat luar biasa, karena mereka akhirnya mempunyai ide untuk pembuatan dekorasi pelaminan yang berasal dari bunga dengan berbahan plastic bekas.

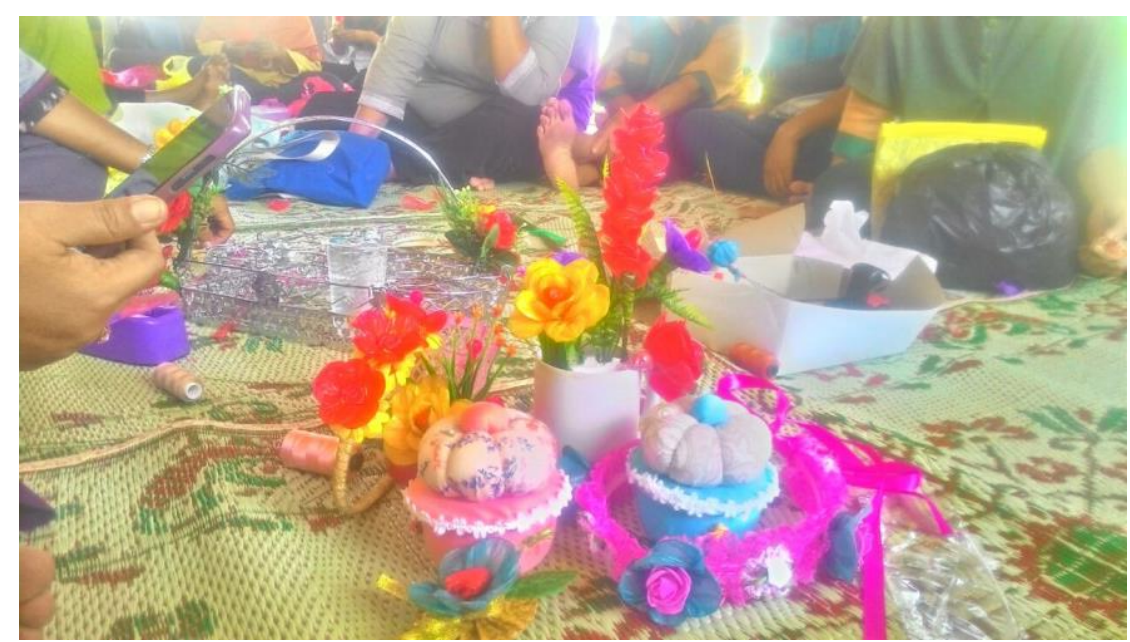

Gambar 2. Produk Olahan Sampah Plastik

Sampah yang berasal dari kertas bekas juga bisa dimanfaatkan menjadi produk yang berpotensi untuk diekspor. Pelatihan diberikan kepada anggota Bank Sampah Rukun Santoso dengan menggunakan teknik yang sederhana serta tidak membutuhkan teknologi yang canggih, hanya memanfaatkan panas dari sinar matahari serta kreativitas dari pembuatnya. Produk olahan sampah dengan bahan kertas bekas terbukti bisa membuka peluang ekspor, hal ini diakui oleh trainer yang digunakan dalam pengabdian pengolahan sampah rumah tangga bahwa mereka mengalami kewalahan ketika terjadi permintaan untuk ekspor sehingga membuka peluang kerjasama dengan Bank Sampah Rukun Santoso untuk mensuplai beberapa produk olahan sampah dari kertas bekas yang bisa dipasok. Adapun produk yang bisa dihasilkan dari pengelolaan sampah kertas bekas adalah untuk tempat buah, lampu hias serta beberapa hiasan rumah.

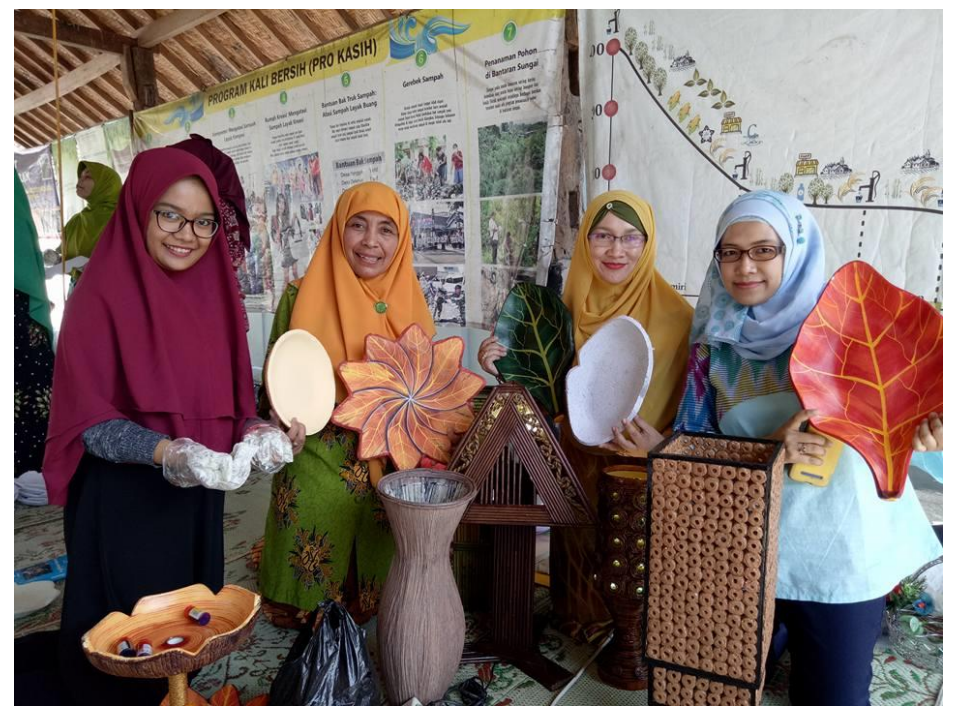

Gambar 3. Produk Olahan Kertas Bekas

Produk yang dihasilkan oleh Bank Sampah Rukun Santoso masih dipasarkan secara sederhana yaitu dari mulut ke mulut dan hanya dipajang pada etalase yang ditaruh di teras rumah salah satu pengelola Bank Sampah. Ini menyebabkan pangsa pasar dari produk olahan sampah ini tidak begitu luas, 
sedangkan fenomena yang terjadi sekarang adalah berkembangnya pasar online yang ditopang dengan kemajuan teknologi serta kepraktisan bagi konsumen. Selain itu, barang-barang yang diproduksi oleh Bank sampah Rukun Santoso belum memiliki merk dagang, ini membuat barang-barang yang dibeli secara borongan oleh pihak ketiga akhirnya diberi merk dagang oleh pihak pemborong tersebut. Ketidakpahaman mengenai brand awareness ini akan merugikan pihak produsen karena membuat pangsa pasar serta keuntungan yang diperoleh sangat terbatas.

\section{Tujuan Pengabdian}

Tujuan umum dari pengabdian ini adalah Implementasi green economy melalui pemanfaatan limbah plastic yang merupakan sampah anorganik dan mempunyai masa terurai yang sangat lama, serta sampah rumah tangga jenis lainnya sehingga pengolahan sampah bisa meningkatkan kesejahteraan manusia serta mengurangi resiko lingkungan. Pengabdian ini dilakukan untuk meningkatkan sinergisitas antara dunia kampus dengan masyarakat khususnya dalam peningkatan kinerja Bank Sampah yang ada di Desa Polanharjo Kabupaten Klaten melalui upaya diversifikasi produk yang dihasilkan dan peningkatan pemasaran serta brand awareness yang selama ini masih dilakukan secara tradisional.

\section{Tinjauan Pustaka}

Penggunaan produk yang ramah lingkungan sangat diperlukan mengingat jumlah penduduk dunia yang semakin meningkat. Pada saat sekarang ini jumlah penduduk dunia mencapai 7,3 juta orang dan pertumbuhan penduduk per tahun mencapai $1,18 \%$. Tantangan yang dihadapi negara-negara sedang berkembang adalah meningkatkan pertumbuhan ekonomi yang pada akhirnya akan meningkatkan polusi dan pembangunan berkelanjutan (Fraccascia, Giannoccaro, \& Albino, 2018).

Pengolahan sampah merupakan permasalahan yang selalu dihadapi baik negara maju maupun berkembang. China menghadapi kendala yang sama sehingga menerapkan kegiatan konstruksi dan pembongkaran sampah dengan system 3R (Reuse, Reduce dan Recycle). Rendahnya kesadaran masyarakat mengenai kegiatan 3R dapat diatasi dengan menghubungkannya dengan kegiatan ekonomi yang menghasilkan pendapatan bagi masyarakat. Rendahnya pasar mengenai produk-produk hasil oalahan sampah juga menyebabkan keinginan masyarakat untuk mengelola sampah menjadi turun. Dukungan pemerintah, adanya jaringan informasi mengenai pemanfaatan teknologi menjadi dasar pengembangan program 3R untuk kelestarian lingkungan (Huang, Wang, Kua, Geng, \& Bleischwitz, 2018).

Keterbatasan pengetahuan masyarakat mengenai pengelolaan sampah menjadi kendala untuk mengelola sampah. Kemiskinan yang ada di suatu daerah bisa diatasi dengan memberdayakan masyarakat untuk mengolah sampah menjadi barang yang bisa menghasilkan pendapatan. Bank sampah memegang peranan dalam meningkatkan kesadaran masyarakat untuk mengelola sampah rumah tangga yang mereka hasilkan. Masyarakat bisa sadar untuk mengelola sampah jika ada contoh nyata yang sudah dilakukan di sekitarnya sehingga akan menambah pengetahuan lingkungan dan meningkatkan pengelolaan limbah sampah untuk keberhasilan proyek daur ulang di masyarakat (Indrianti, 2016)

\section{Metode Pengabdian}

Metode pelaksanaan kegiatan menjelaskan beberapa solusi yang ditawarkan untuk mengatasi permasalahan-permasalahan yang dihadapi oleh pengurus maupun anggota dari Bank Sampah di Desa Polanharjo Kabupaten Klaten. Berikut ini disajikan tabel mengenai permasalahan yang dihadapi, solusi yang ditawarkan dan metode pelaksanaan pada masing-masing tahun. 
Jurnal SEMAR Vol. 8 No. 2, 2019 hal. $30-38$

ISSN: 2302-3937 | Copyright @ LPPM Universitas Sebelas Maret Homepage: https://jurnal.uns.ac.id/jurnal-semar

Tabel 2. Permasalahan, Solusi dan Metode Pelaksanaan Pengabdian

\begin{tabular}{|c|c|c|}
\hline Permasalahan & Solusi & Metode Pelaksanaan \\
\hline $\begin{array}{l}\text { 1. Limbah rumah tangga } \\
\text { berupa kain perca belum } \\
\text { bisa dimanfaatkan secara } \\
\text { maksimal }\end{array}$ & \begin{tabular}{lrr} 
- Meningkatkan & \multicolumn{2}{c}{ keahlian } \\
anggota bank sampah untuk \\
memanfaatkan limbah kain \\
perca.
\end{tabular} & $\begin{array}{l}\text { Melakukan pelatihan guna } \\
\text { memanfaatkan limbah kain } \\
\text { perca menjadi produk yang } \\
\text { berdaya jual tinggi. }\end{array}$ \\
\hline $\begin{array}{l}\text { 2. Pemasaran produk yang } \\
\text { tidak menggunakan } \\
\text { promosi hanya dari mulut } \\
\text { ke mulut }\end{array}$ & - Peningkatan daerah pemasaran & $\begin{array}{l}\text { Pembuatan berbagai sarana } \\
\text { promosi, bisa menggunakan } \\
\text { internet }\end{array}$ \\
\hline $\begin{array}{l}\text { 3. Belum ada branding pada } \\
\text { produk yang dihasilkan } \\
\text { oleh Bank Sampah yang } \\
\text { ada di Desa Polanharjo }\end{array}$ & $\begin{array}{l}\text { - Brand awareness kepada } \\
\text { pengurus dan anggota Bank } \\
\text { Sampah terhadap produk yang } \\
\text { dihasilkannya sehingga } \\
\text { menjadi salah satu produk } \\
\text { unggulan di Kabupaten Klaten }\end{array}$ & $\begin{array}{l}\text { Pendampingan pemilihan } \\
\text { brand/ merk untuk produk } \\
\text { olahan sampah. }\end{array}$ \\
\hline $\begin{array}{l}\text { 4. Produk yang dihasilkan } \\
\text { oleh Bank Sampah di } \\
\text { Desa Polanharjo dibeli } \\
\text { oleh pihak lain dan dijual } \\
\text { lagi dengan merk pihak } \\
\text { pembeli tersebut }\end{array}$ & $\begin{array}{l}\text { - Memberikan label pada produk } \\
\text { olahan sampah yang dihasilkan } \\
\text { oleh Bank Sampah di } \\
\text { Polanharjo. }\end{array}$ & $\begin{array}{l}\text { Pemberian bantuan label } \\
\text { untuk dipasang pada produk } \\
\text { olahan sampah }\end{array}$ \\
\hline
\end{tabular}

\section{Pelaksanaan Pengabdian}

Pelaksanaan pengabdian dilakukan pada hari Sabtu, tanggal 2 Juni 2018 yang diikuti oleh pengurus Bank Sampah Rukun Santoso, anggota bank sampah serta masyarakat yang tertarik untuk mengolah kain perca yang tinggal di sekitar tempat bank sampah tersebut. Trainer pada pelatihan pengelolaan kain perca ini sebanyak 2 orang, dimana mereka akan mengolah kain perca menjadi lukisan dengan bahan baku kain perca serta beberapa produk hiasan untuk rumah tangga.
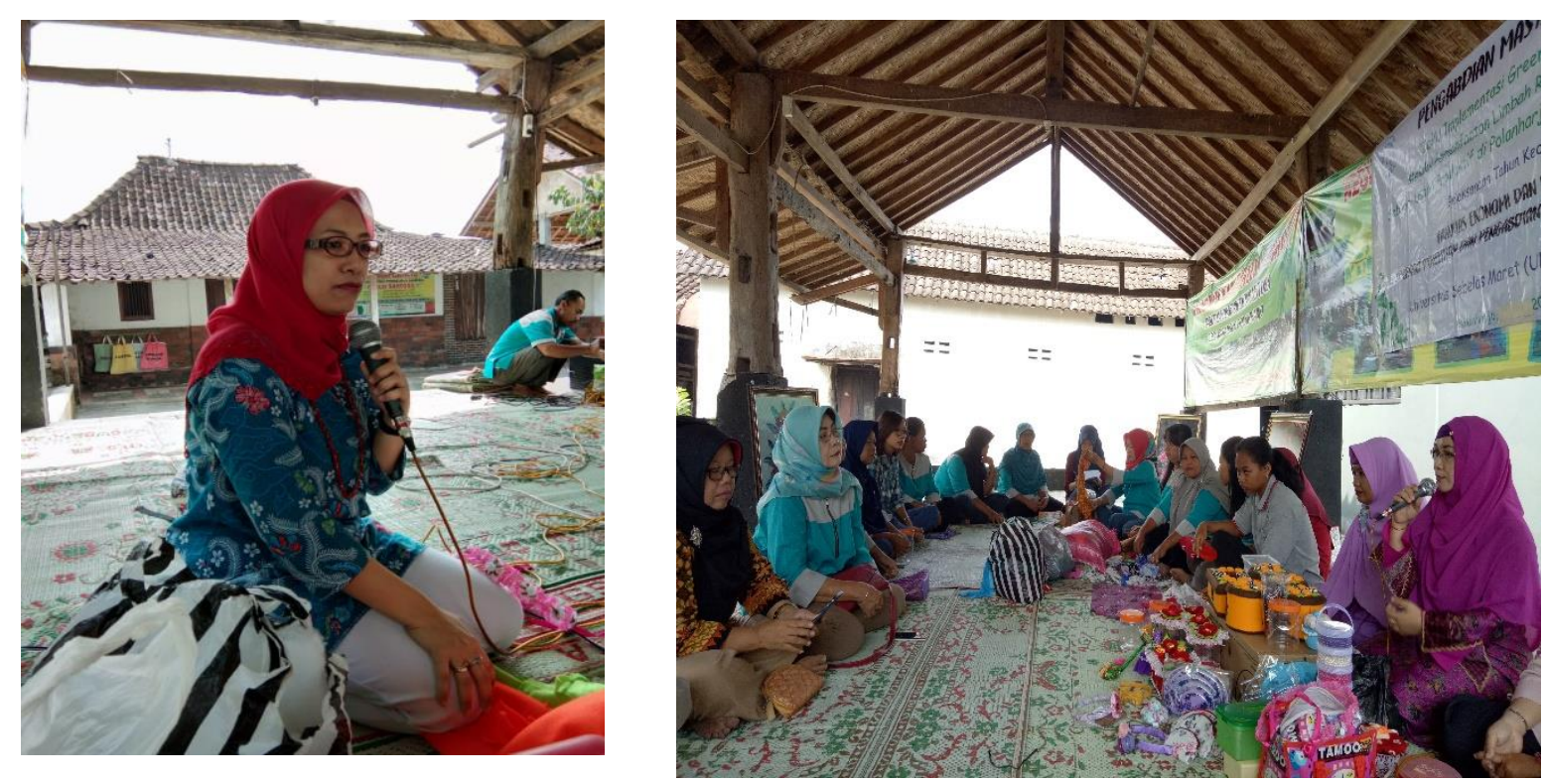

Gambar 4. Proses Pelatihan Pengolahan Limbah Kain Perca 
Jurnal SEMAR Vol. 8 No. 2, 2019 hal. $30-38$

ISSN: 2302-3937 | Copyright (C LPPM Universitas Sebelas Maret Homepage: https://jurnal.uns.ac.id/jurnal-semar

Pelaksanaan pengabdian ini diikuti anggota bank sampah serta masyarakat yang tertarik untuk mengelola limbah rumah tangga, dimana pengolahan limbah kain perca yang pertama adalah pembuatan lukisan yang berasal dari kain perca. 1. Lukisan Kain Perca

Adapun bahan-bahannya adalah :
a. Kain perca
b. Triplek
c. Gunting
d. Lem kertas
e. Pigura
f. Kaca

Cara pembuatan :

a. Potong-potong kain perca sesuai dengan motif yang ingin dibuat dalam lukisan kain perca, bisa dipotong dengan menggunakan pola yang diinginkan, bisa pula mengambil pola secara utuh yang ada pada kain perca tersebut (contohnya pola bunga bisa dipotong utuh).

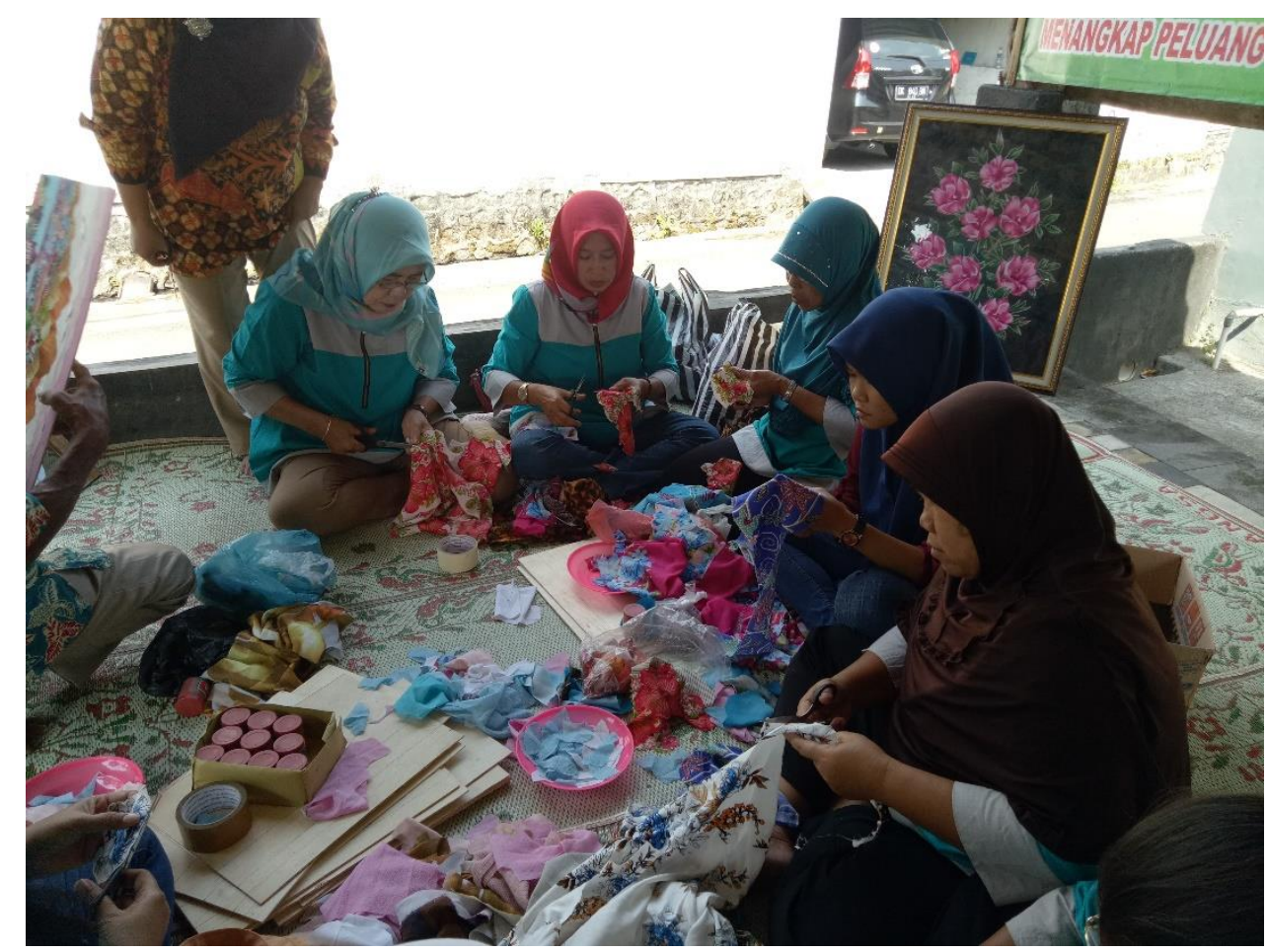

b. Lembaran kain ditempelkan dan dilem pada semua permukaan triplek untuk memberikan warna dasar pada lukisan kain perca nantinya. 
Jurnal SEMAR Vol. 8 No. 2, 2019 hal. $30-38$

ISSN: 2302-3937 | Copyright (C LPPM Universitas Sebelas Maret Homepage: https://jurnal.uns.ac.id/jurnal-semar

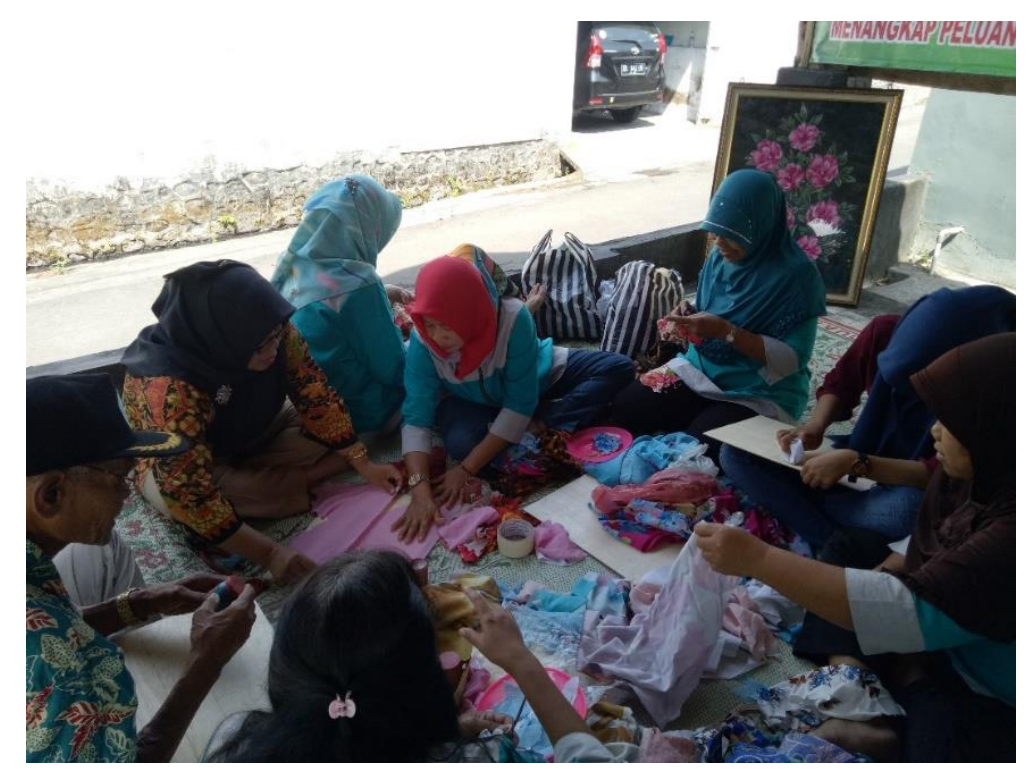

c. Potongan kain perca tersebut ditempel pada triplek sesuai dengan gambar/ pola lukisan yang dikendaki hingga menutupi seluruh permukaan triplek.

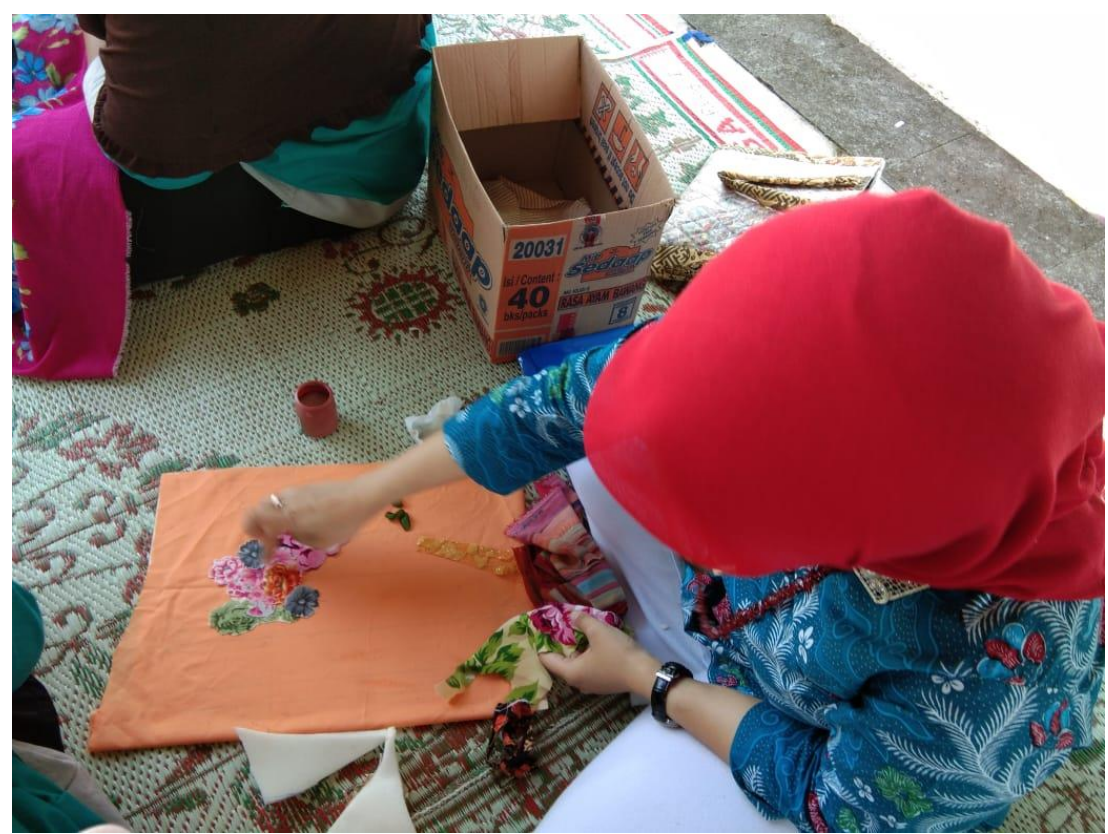

d. Kemudian dipasang kaca, figura serta dipaku pada bagian belakang tripleks tersebut.

e. Lukisan dari kain perca sudah jadi dan siap untuk dipasarkan. 
Jurnal SEMAR Vol. 8 No. 2, 2019 hal. 30 - 38

ISSN: 2302-3937 | Copyright (C) LPPM Universitas Sebelas Maret Homepage: https://jurnal.uns.ac.id/jurnal-semar

Berikut adalah beberapa foto hasil lukisan dengan kain perca :
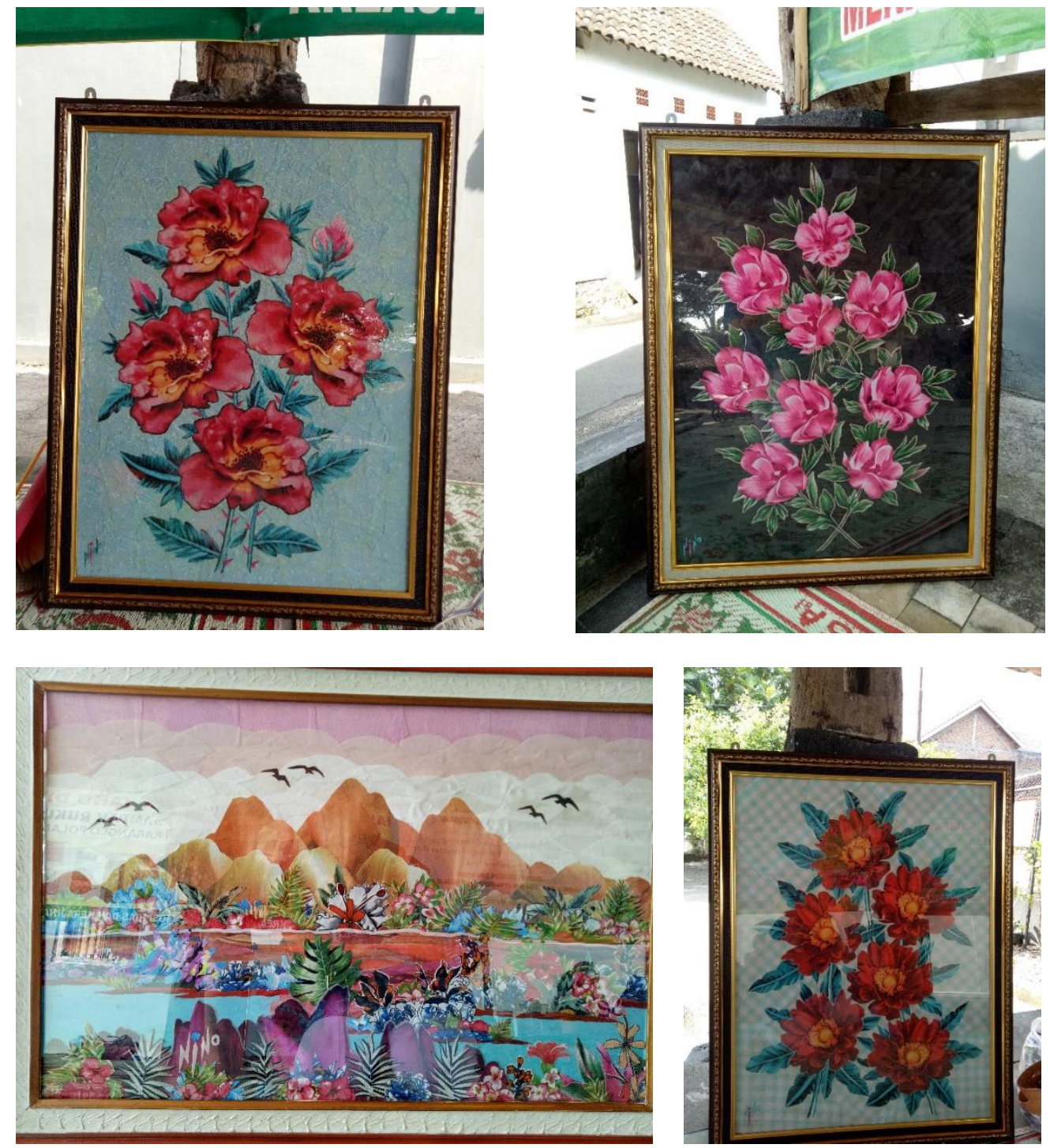

Gambar 3.1. Lukisan Kain Perca

\section{Kesimpulan}

Pengabdian yang dilakukan untuk mengolah limbah kain perca dijadikan lukisan perca serta beberapa pernak pernik perhiasan rumah tangga mendapatkan antusias dari anggota Bank Sampah Rukun Santoso serta warga masyarakat yang tinggal di sekitar bank sampah tersebut. Selama ini, kain perca belum bisa diolah menjadi barang dengan nilai tinggi. Bank Sampah Rukun Santoso hanya mengolah sampah yang berasal dari plastic bekas pembungkus minuman instan untuk dijadikan produk unggulannya. Adanya training yang diberikan oleh tim pengabdi membuat varian produk yang dihasilkan oleh bank sampah tersebut semakin banyak sehingga kesempatan untuk meningkatkan pendapatan semakin meningkat pula.

Kesadaran mengenai pentingnya pemberian merk pada produk - produk yang dihasilkan oleh Bank Sampah Rukun Santoso sedang disosialisasikan. Tidak adanya merk yang menempel pada produk yang dihasilkan pada jangka panjang akan memberikan kerugian kepada bank sampah tersebut, karena bisa 
dimanfaatkan oleh pihak ketiga dengan membeli produk yang dihasilkan oleh Bank Sampah Rukun Santoso dan diberikan merk mereka. Hal ini akan mengakibatkan produk-produk unggulan tersebut dikira sebagai produk hasil pembuatan pihak ketiga.

\section{Daftar Pustaka}

Aisah, Winda Yuni. (2013). Analysis Pengelolaan Sampah oleh Dinas Kebersihan dan Pertamanan (DKP) Kota Surabaya. Skripsi. Surabaya. Universitas Negeri Surabaya.

Andin Z.L. Jr., (2006). Implementation of the 3Rs in the Philippines. Presented at theSenior Officials Meeting on the 3R Initiative, Tokyo, March 6-8, 2006.

AtalyeA.S., (2000). Plastics in Packaging. London. McGraw-Hill.

Ayuningtyas, Tisna. (2010). Kajian Pengelolaan Sampah di Kecamatan Bubutan Kota Surabaya. Tesis. Tidak untuk dipublikasikan. Surabaya. Teknik Lingkungan ITS.

Badan Pusat Statistik. (2012). Buku Putih Sanitasi Kabupaten Klaten.

Barr S, Gilg AW, Ford NJ. (2001). Differences Between Household Waste Reduction, Reuse and Recycling Behaviour: a Study of Reported Behaviours, Intentions and Explanatory Variables. Environmental \& Waste Management 2001;4(2):69-81.

Jibril, Jibril Dan'Azimi., Sipan, Ibrahim Bin., Sapri, Maimunah., Shika, Suleiman Aliyu., Isa, Mona., Abdullah, Shahabudin. (2012). 3R's Critical Succes Factor in Solid Waste Management System for Higher Educational Institutions. Procedia - Social and Behavioral Sciences 65 ( 2012 ) 626 -631 .

Kementerian Negara Lingkungan Hidup Republik Indonesia (KNLH). (2008). Panduan Praktis Pemilahan Sampah. Kerjasama dengan Japan International Cooperation Agency (JICA). Jakarta.

Lacoste, E. and Chalmin. P. (2007). From Waste to Resource : 2006 World Waste Survey. Paris. Economica.

Moh, YiingChiee., and Manaf, Latifah Abd. (2017). Solid Waste Management Transformation and Future Challenges of Source Separation amd Recycling Practice in Malaysia. Resources, Conservation and Recycling 116 (2017) 1-14 diakses pada tanggal 9 Februari 2017 pada jo ur nal home p age: www.elsevier.com/locate/resconrec.

Neonaka, A. (2008). Kesadaran Lingkungan. Jakarta. PT Rinika Cipta.

Niyah, Nur Vita Adin. (2016). Efektivitas Kebijakan Pengelolaan Sampah di Kabupaten Klaten. Skripsi. Yogyakarta. Universitas Negeri Yogyakarta. Diakses pada tanggal 21 Januari 2017. http://eprints.uny.ac.id/43657/1/Skripsi\%20Full\%20Nur\%20Vita\%20Adin\%20Niyah\%201241 7141015.swf

Novianty, Mita. (2014). Dampak Program Bank Sampah Terhadap Sosial Ekonomi Masyarakat di Kelurahan Binjai,Kecamatan Medan Desai, Kota Medan.Medan.Universitas Sumatera Utara Diakses tanggal 31 Januari2017.http://jurnal.usu.ac.id/index.php/ws/article/view/6231

Nurhayati, N. (2013). Pencemaran Lingkungan. Bandung. Penerbit Yrama Widya.

Sudrajat, R. (2007). Mengelola Sampah Kota. Jakarta. Penebar Swadaya.

Thomas, C., Sharp, V., 2013. Understanding the normalisation of recyclingbehaviour and its implications for other pro-environmental behaviours: areview of social norms and recycling. Resour. Conserv. Recycl. 79, 11-20,http://dx.doi.org/10.1016/j.resconrec.2013.04.010.

Undang-Undang Nomor 18 Tahun 2008 tentang Pengelolaan Sampah. 